\title{
Prevalence and risk factors associated with HIV/hepatitis B and HIV/hepatitis C co- infections among people who inject drugs in Mozambique
}

Cynthia Semá Baltazar ${ }^{1,2^{*}}$ (D, Makini Boothe ${ }^{2,3}$, Timothy Kellogg ${ }^{3}$, Paulino Ricardo ${ }^{1}$, Isabel Sathane ${ }^{4}$, Erika Fazito ${ }^{5}$, Henry F. Raymond ${ }^{3,6}$, Marleen Temmerman ${ }^{2,7}$ and Stanley Luchters $2,8,9,10$

\begin{abstract}
Background: There is scare information about HIV co-infections with hepatitis B virus (HBV) and/or hepatitis C virus $(\mathrm{HCV})$ among People Who Inject Drugs (PWID) in Mozambique. This information is critical to ensure the treatment necessary to decrease the progression of liver disease and the transmission of both HIV and hepatitis. We assess the prevalence of HIV, HBV and HCV co-infections as well as associated risk factors among PWID.

Methods: The first Bio-Behavioral Surveillance Survey was conducted in 2013-2014 among persons who selfreported to have ever injected drugs. Using respondent-driven sampling, PWID aged 18 years and older were recruited in two cross-sectional samples in Maputo and Nampula/Nacala, two large urban centers of Mozambique. Rapid screening of HIV, HBV (HBsAg) and HCV was performed on site. Data from participants in both cities were pooled to conduct RDS-weighted bivariate analyses with HIV/HBV and HIV/HCV co-infections as separate outcomes. Unweighted bivariate and multivariate logistic regression analyses were conducted to assess correlates of coinfection.

Results: Among 492 eligible PWID, 93.3\% were male and median age was 32 years [IQR: 27-36]. HIV, HBV and HCV prevalence were respectively $44.9 \%$ (95\% Cl:37.6-52.3), 32.8\% (95\% Cl:26.3-39.5) and 38.3 (95\% Cl:30.6-45.9). Coinfections of HIV/HBV, HIV/HCV and HIV/HBV/HCV were identified in 13.1\% (95\% Cl:7.2-18.9), 29.5\% (95\% Cl:22.236.8) and 9.2\% (95\% Cl:3.7-14.7) of PWID, respectively. Older age, history of needle/syringe sharing and history of injection with used needle/syringe was associated with HIV/HBV co-infection. Living in Maputo city, have older age, history of needle/syringe sharing and history of injection with used needle/syringe was associated with HIV/HCV coinfection.

\footnotetext{
*Correspondence: cynthiasema@yahoo.com; cynthia.baltazar@ins.gov.mz

'Instituto Nacional de Saúde (INS), Maputo, Mozambique

${ }^{2}$ Department of Public Health and Primary Care, Faculty of Medicine and Health Sciences, Ghent University, Ghent, Belgium

Full list of author information is available at the end of the article
}

(C) The Author(s). 2020 Open Access This article is licensed under a Creative Commons Attribution 4.0 International License, which permits use, sharing, adaptation, distribution and reproduction in any medium or format, as long as you give appropriate credit to the original author(s) and the source, provide a link to the Creative Commons licence, and indicate if changes were made. The images or other third party material in this article are included in the article's Creative Commons licence, unless indicated otherwise in a credit line to the material. If material is not included in the article's Creative Commons licence and your intended use is not permitted by statutory regulation or exceeds the permitted use, you will need to obtain permission directly from the copyright holder. To view a copy of this licence, visit http://creativecommons.org/licenses/by/4.0/. The Creative Commons Public Domain Dedication waiver (http://creativecommons.org/publicdomain/zero/1.0/) applies to the data made available in this article, unless otherwise stated in a credit line to the data. 
(Continued from previous page)

Conclusion: There is a high burden of HBV and HCV among HIV-infected PWID in Mozambique. Our results highlight the need for targeted harm reduction interventions that include needle exchange programs and integrated services for the diagnosis and treatment of HIV, HBV and HCV to address these epidemics among PWID. Efforts should be made to strengthen ART coverage in the population as an important treatment strategy for both viruses.

Keywords: People who inject drugs, HIV, Hepatitis B, Hepatitis C, Co-infections, Respondent driven sampling, Mozambique

\section{Background}

People who Inject Drugs (PWID) are among the most vulnerable to HIV infection, with an estimated prevalence of $17.8 \%$ globally and $8.3 \%$ in the Sub-Saharan African region [1]. PWID are considered a key population for targeted HIV prevention and treatment efforts due to their illicit drug use and associated social stigma, which often makes it difficult to obtain information about this population and increases their vulnerability to HIV transmission $[2,3]$.

HIV ranks among one of the highest HIV prevalence rates among adults aged 15-49 years old age (13.2\%), largely due to heterosexual transmission [4]. Although the 3rd National HIV Strategic Plan recognized PWID as a key population in 2010, there has been a lack of information about the population size, HIV prevalence and their utilization of health services [5]. To address this gap, the first Bio-Behavioral Surveillance (BBS) survey among PWID was conducted in two main urban cities between 2013 and 2014, using respondent-driven sampling (RDS). This study estimated HIV prevalence at $50.1 \%$ in Maputo (95\% CI: $40.1-59.0$ ) and $19.9 \%$ in Nampula/Nacala (95\% CI: 10.9-29.2), where the greater burden of HIV observed in the southern region is consistent with the dynamics of the HIV epidemic in the country $[6,7]$,.

In addition to HIV, viral hepatitis remains an important global health issue, characterized by high prevalence, high burden of morbidity and mortality, and suboptimal diagnosis and management approaches [8-10]. Viral hepatitis are the most common viral infections affecting PWIDs $[10,11]$. HIV and viral hepatitis infections share common transmission routes, risk behaviors and their co-infection represents a serious global concern resulting in high morbidity and mortality rates $[11,12]$. HIV infection affects the natural course of hepatitis B virus (HBV) and hepatitis $\mathrm{C}$ virus (HCV), promoting faster progression to chronicity, liver fibrosis, and malignancy [2, 9-11]. The BBS among PWID in Mozambique estimated HBV prevalence at 32.1 and $36.4 \%$, and HCV prevalence at 44.6 and $7.0 \%$, in Maputo and Nampula/Nacala respectively. Data about $\mathrm{HBV}$ and $\mathrm{HCV}$ among the general population in Mozambique is limited to a few studies in the southern region of the country $[13,14]$.
Global health targets to reduce HIV and viral hepatitis infections have been established $[15,16]$. Strengthening the prevention and treatment of substance abuse, including narcotic drug abuse, is listed as one of the priorities of the United Nations 2030 Agenda for Sustainable Development Goals (Goal 3.5) [17]. Integrated harm reduction programs, in some countries have been designed to address the assumption that the prevention of HIV in PWID will also prevent hepatitis given their similar modes of transmission and high-risk populations.

PWID have the highest burden of HIV among key population groups in Mozambique and yet there continues to be lack of integrated prevention and treatment services $[18,19]$. In a country with one of the highest HIV prevalence rates in the world, understanding the epidemiology of HIV, HBV and HCV among PWID is critical in order to design effective and efficient prevention and treatment programs. Neglecting to implement targeted services has the potential to compromise the success of the overall HIV response in the country.

As such, the objective of this secondary analysis was to evaluate $\mathrm{HIV} / \mathrm{HBV}$ and HIV/HCV co-infections among PWID in Mozambique and to assess associated risk factors. The findings from this paper emphasize the importance of focusing on the dynamics of this population and could also support the current drafting of the $\mathrm{Na}$ tional Harm Reduction Plan. The population has the highest burden of HIV among key population groups and yet there continues to be lack of integrated services for HIV and viral hepatitis. Since Mozambique has one of the highest HIV prevalence rates in the world, neglecting to implement targeted services has the potential to compromise the success of HIV prevention and control programs in the country. The findings from this paper emphasize the importance of focusing on the dynamics of this population and could also support the current drafting of the National Harm Reduction Plan.

\section{Methods}

Study design, target population, recruitment, and sampling

We conducted a cross-sectional survey using RDS sampling methodology in the two urban cities of Maputo 
and Nampula/Nacala, located in the South and North regions of Mozambique, respectively. This survey methodology has been widely used among hard-to-reach populations to estimate HIV prevalence and associated risk factors, and also to evaluate access and use of health services [6, 7, 20-25]. Recruitment occurred between September 2013 and March 2014. The recruitment procedures have been published previously $[6,7]$.

Participants were be eligible for inclusion in the study, if they were at least 18 years of age; lived, worked or socialized in the survey area within the last 12 months; injected drugs without a medical prescription within the last 12 months (in December 2013, eligibility requirements were expanded to anyone who had ever injected drugs at any point in their lives to overcome recruitment challenges). They also needed to be in possession of a valid recruitment coupon and have and mental ability to provide written informed consent. Participants received a prevention and hygiene kit, $50 \mathrm{MZN}(\sim 2.50)$ in cash to compensate for transportation costs, and $50 \mathrm{MZN}$ worth of mobile phone credit for every successfully referred peer who participated in the survey.

A behavioral questionnaire was administered, and blood sample collected for on-site rapid tests for HIV, $\mathrm{HBV}$ and HCV. The HIV rapid testing procedures adhered to the national algorithm using Determine ${ }^{\mathrm{Tm}}$ HIV1/2 (Alere, USA), followed by a confirmatory test using Uni-Gold HIV ${ }^{\mathrm{m}}$ (Trinity Biotech, Ireland). The results of the rapid HIV tests, together with self-reported prior HIV-positive test results, were used to estimate HIV prevalence. On-site rapid HBV testing was done using Alere Determine ${ }^{\circ}$ HbsAg (Abbott Laboratories, UK), to detect surface antigen, and HCV testing used SD Bioline HCV (Standard Diagnostics, Korea). Participants with reactive $\mathrm{HbsAg}$ results or $\mathrm{HCV}$ antibodies were considered as having an active HBV and HCV infection, respectively; none of the tests were able to determine if infection was acute or chronic. Participants with positive results for any of the laboratory tests were referred to a nearby health facility, identified during the formative assessment, where trained teams were ready to link them to treatment services $[6,7]$.

Dried Blood Spot (DBS) were also collected and analyzed at the central laboratory of the National Institute of Health. Central-level HBV tests were performed at the National Institute of Health Laboratory using ELISA Murex ${ }^{\bullet}$ HBsAg Version 3 (Murex Biotech Limited, UK) and were used to estimate HBV prevalence in the survey; centralized HCV testing was not performed because a serologic anti-HCV assay using DBS had not been validated by the National Reference Laboratory at the time of the survey $[6,7]$.

Separate informed consent was required for behavioral questionnaire and each separate laboratory test; 47 participants did not consent to rapid HIV testing, two participants did not consent for HBV, and 46 participants did not consent to $\mathrm{HCV}$ testing.

\section{Behavioral indicators}

Demographic information and self-reported sexual and injection risk behaviors were recorded through face-toface interviews using a structured questionnaire delivered by trained interviewers. The network size was assessed by asking: "Approximately how many people who inject drugs do you think live in and around the city of $<$ Maputo or Nampula $>$ ?"

\section{Statistical analysis}

For the purpose of this analysis, data on survey participants from both cities were pooled given the low sample size. RDS-adjusted pooled descriptive statistics were used to describe participants demographic characteristics, drug use behaviors, HIV/HBV, HIV/HCV, HIV/ $\mathrm{HBV} / \mathrm{HCV}$ co-infections, as well as singular infections. Site level analysis of these variables were adjusted for the sampling method where the adjustment takes into consideration the probability of each participants inclusion in the study based on their self-reported network size. Pooled estimates were weighted by the size of the PWID population in each study site, based on four approaches to produce estimates of the PWID population size in each city. The median of the four estimates in each site resulted in a PWID population size of 1684 in Maputo and 520 in Nampula. These RDS-adjusted pooled prevalence estimates and 95\% confidence intervals (CI) were obtained using the aggregate estimate feature within the RDS Analyst suite of tools [26].

Unadjusted pooled bivariate and multivariable logistic regression analyses were conducted to identify correlates for the two outcomes of interest: HIV/HBV and HIV/ $\mathrm{HCV}$. Correlates included in the final model were selected based on literature review and the results of the bivariate association $(p<0.05)$ with the outcomes of interest. This analysis was conducted using R Statistical Software v.3.1.1 (r Development Core Team, Vienna, Austria).

\section{Ethical considerations}

This is a secondary data analysis from a survey protocol that was approved by the Mozambican National Bioethics Committee for Health (CNBS) (46/CNBS/13) and the Institutional Review Board of the University of California at San Francisco (13-10,699); the US Centers for Disease Control and Prevention (CDC) determined the protocol to be research where CDC was not engaged. Participants provided informed consent for study participation and no personal identifying information was collected. 
Table 1 People who Inject Drugs population description in two urban settings in Mozambique, 2013-2014 (N=492)

\begin{tabular}{|c|c|c|c|}
\hline \multirow[t]{2}{*}{ Characteristics } & \multicolumn{3}{|c|}{ PWID Study Population } \\
\hline & $n$ & $\%$ unweighted & RDS-weighted \% (95\%Cl) \\
\hline \multicolumn{4}{|l|}{ City } \\
\hline Maputo & 353 & 71.7 & - \\
\hline Nampula/Nacala & 139 & 28.3 & - \\
\hline Crude median age (years) [IQR $]^{\mathrm{a}}$ & \multicolumn{2}{|c|}{$32[27-36]$} & \\
\hline \multicolumn{4}{|l|}{ Age group (years) } \\
\hline $18-24$ & 92 & 18.7 & $18.2(1.3-23.3)$ \\
\hline$\geq 25$ & 400 & 81.3 & $81.8(76.7-86.8)$ \\
\hline \multicolumn{4}{|l|}{ Gender } \\
\hline Male & 467 & 94.9 & $93.3(90.3-96.3)$ \\
\hline Female & 25 & 5.1 & $6.7(3.6-9.7)$ \\
\hline \multicolumn{4}{|l|}{ Marital status } \\
\hline Single/never married & 289 & 58.7 & $60.9(55.6-66.3)$ \\
\hline Cohabitating/married & 103 & 20.9 & $20.5(13.9-26.9)$ \\
\hline Widowed/divorced/separated & 100 & 20.3 & $18.6(13.1-24.1)$ \\
\hline \multicolumn{4}{|l|}{ Education } \\
\hline No formal education/primary & 210 & 42.8 & $50.1(44.0-57.2)$ \\
\hline Secondary/higher & 281 & 57.2 & $49.9(42.8-55.9)$ \\
\hline \multicolumn{4}{|l|}{ Religion } \\
\hline Christian (catholic, evangelical, protestant) & 247 & 50.2 & $54.8(48.3-61.3)$ \\
\hline Muslim & 143 & 29.1 & $25.5(19.5-31.5)$ \\
\hline Other/None & 102 & 20.7 & $19.7(14.4-24.9)$ \\
\hline \multicolumn{4}{|l|}{ Age of first drug use (years) } \\
\hline$<18$ & 56 & 11.7 & $7.9(0.1-14.9)$ \\
\hline $18-24$ & 235 & 49.1 & $50.9(45.8-55.9)$ \\
\hline$\geq 25$ & 188 & 39.2 & $41.2(34.5-47.8)$ \\
\hline \multicolumn{4}{|l|}{ No of sexual partners, last 12 months, males only $(N=456)^{b}$} \\
\hline 0 & 94 & 20.6 & $19.9(15.5-24.3)$ \\
\hline 1 & 95 & 20.8 & $24.2(19.0-29.4)$ \\
\hline$\geq 2$ & 267 & 58.6 & $55.9(49.6-62.1)$ \\
\hline \multicolumn{4}{|l|}{ Frequency of drug injection in the last 12 months } \\
\hline Did not use & 25 & 5.1 & $7.9(4.5-11.8)$ \\
\hline Few times per year or month & 192 & 39.0 & $40.0(34.0-46.1)$ \\
\hline Daily & 275 & 55.9 & $51.9(45.4-58.4)$ \\
\hline Had access to new syringes in the past 12 months $(N=491)$ & 425 & 86.6 & $87.3(82.6-92.1)$ \\
\hline Ever shared needles or syringes & 258 & 52.4 & $48.8(42.1-55.6)$ \\
\hline Shared syringes in the last month & 146 & 29.7 & $27.2(20.5-33.8)$ \\
\hline Ever injected with a previously used needle/syringe $(N=491)$ & 391 & 79.6 & $74.8(68.6-81.1)$ \\
\hline Ever shared any other injection equipment ${ }^{c}$ & 158 & 32.1 & $33.6(26.9-40.4)$ \\
\hline \multicolumn{4}{|l|}{ Had unprotected sexual intercourse at last sex $(N=491)$} \\
\hline Yes & 214 & 43.6 & $44.3(37.6-51.0)$ \\
\hline No, used a condom & 173 & 35.2 & $36.1(30.2-42.0)$ \\
\hline Not sexually active & 104 & 21.2 & $19.4(13.1-25.8)$ \\
\hline Received condoms in the past 12 months $(N=489)$ & 188 & 38.4 & $34.6(28.6-40.6)$ \\
\hline Ever incarcerated & 328 & 66.7 & $64.3(58.2-70.6)$ \\
\hline
\end{tabular}

a IQR Interquartile range

b 11 male subjects did not report number of sexual partners

c Other includes spoon, cotton or cleaning agent 


\section{Results}

\section{Population characteristics}

A total of 353 PWID were enrolled in the survey in Maputo and 139 in Nampula/Nacala. When pooling results, the majority of participants were male (93.3, 95\%CI: 90.3-96.3), and the median age was 32 years. Half (49.9, 95\%CI: 42.8-55.9) had completed secondary or higher education. The majority of participants were Christian (54.8, 95\%CI: 48.3-61.3) and were single or never married (60.9, 95\%CI: 55.6-66.3). Table 1 presents the RDS-Adjusted characteristics of the survey participants.

About half the participants (50.9, 95\% CI: 45.8-55.9) reported initiation of injection drug use when they were between the ages of 18-24 years and reported daily drug injection during the past year (51.9, 95\%CI: 45.4-58.4). Although $87.3 \%$ (95\%CI: 82.6-92.1) of participants stated that they had access to brand new syringes, sharing was a common practice and $48.8 \%$ (95\%CI: $42.1-$ 55.6) of participants reported having shared a needle or syringe at least once in their lifetime, while a quarter (27.2, 95\%CI: 20.5-33.8) reported sharing in the month prior to the survey. Nearly two-thirds of participants (64.3, 95\%CI: 58.2-70.6) reported that they have ever been incarcerated (Table 1).

\section{Prevalence of HIV, HBV, HCV and co-infections}

As presented in Table 2, HIV prevalence among participants was $44.9 \%$ (95\% CI: 37.6-52.3). The prevalence of HBsAg among PWID was 32.8\% (95\%CI: 26.3-39.5) and $38.3 \%$ for hepatitis $C$ virus antibody (95\%CI: 30.6-45.9). Co-infection of $\mathrm{HIV} / \mathrm{HBV}$ was found in 13.1\% (95\%CI: 7.2-18.9), and $\mathrm{HIV} / \mathrm{HCV}$ co-infection was found in 29.5\% (95\%CI: 22.2-36.8) of PWID. Triple infection of $\mathrm{HIV} / \mathrm{HBV} / \mathrm{HCV}$ was identified in $9.2 \%$ (95\%CI: 3.7-14.7) of PWID.

\section{Associated risk factors for HIV/HBV and HIV/HCV co- infection}

In multivariate analysis, older age (aOR 12.9, 95\%CI: 3.6-233.5), ever shared needles/syringes (aOR 1.8, $95 \% \mathrm{CI}: 1.2-3.4)$ and ever injected with a previously used needle/syringe (aOR 5.3, 95\%CI: 1.9-22.4) was associated with $\mathrm{HIV} / \mathrm{HBV}$ co-infection (Table 3). Living in Maputo (aOR 4.4, 95\%CI: 2.0-11.1), older age (aOR 22.8, 95\% CI: 4.6-414.6), ever sharing needles or syringes (aOR 4.0, 95\%CI 2.1-7.7), ever injecting with a previously used needle/syringe (aOR 12.1, 95\%CI: 4.1-46.3) were associated with $\mathrm{HIV} / \mathrm{HCV}$ co-infection (Table 4).

\section{Discussion}

Our data indicates that approximately one-third of PWID participants have serological evidence of HIV (44.9\%), HBV (32.8\%) or HCV (38.3\%), which is substantially higher than prevalence rates estimated for PWID reported from sub-Saharan African region for the three infections at $18.3,3.7,21.8 \%$, respectively [1].

Our prevalence of $\mathrm{HIV} / \mathrm{HBV}$ co-infection (13.1\%) fall within the range observed in a previous study in the sub-Saharan region (0-28.4\%) [27]. The HIV/ HBV co-infection estimate is higher than that among other population groups in the Mozambique where there was an estimated $4.9 \%$ of youths HIV infected in Maputo [13] and 9.1\% of untreated HIV-infected adults [14]. The hepatitis B vaccine was only introduced into the Mozambican national vaccine program for children in 2001 [28]. Although the HBV vaccine is not widely available for the adult population, anti-retroviral therapy (ART) based-on tenofovir (TDF), lamivudine (3TC) and efavirenz (EFV) has dual treatment benefits for both HBV and HIV infections [9, 12, 27].

The prevalence of $\mathrm{HIV} / \mathrm{HCV}$ co-infection among PWID participants found in this study (29.5\%) was substantially higher than the estimated prevalence in the sub-Saharan region (5.7\%). Only a few studies have investigated $\mathrm{HIV} / \mathrm{HCV}$ co-infection among PWID in the sub-Saharan region, and there is no previous empirical estimation HIV/HCV co-infection in Mozambique. Despite the lack information, there is clear evidence that HIV is associated with a higher risk of infection with $\mathrm{HCV}$ due to the similar mode of transmission though infected blood [29, 30].

Table 2 Prevalence of HIV, hepatitis and co-infections in PWID in two urban settings in Mozambique, 2013-2014

\begin{tabular}{|c|c|c|c|}
\hline \multirow[t]{2}{*}{ Characteristics } & \multicolumn{3}{|c|}{ PWID Study Population } \\
\hline & $n$ & $\%$ unweighted & RDS-weighted \% (95\%Cl) \\
\hline HIV infected $\left(N=445^{a}\right)$ & 204 & 45.8 & $44.9(37.6-52.3)$ \\
\hline HBV infected $\left(N=490^{a}\right)$ & 164 & 33.5 & $32.8(26.3-39.5)$ \\
\hline HCV infected $\left(N=446^{a}\right)$ & 163 & 36.5 & $38.3(30.6-45.9)$ \\
\hline HIV/HBV co-infection $\left(N=444^{a}\right)$ & 59 & 13.3 & $13.1(7.2-18.9)$ \\
\hline HIV/HCV co-infection $\left(N=424^{a}\right)$ & 124 & 29.2 & $29.5(22.2-36.8)$ \\
\hline HIV/HBV/HCV co-infection $\left(N=423^{a}\right)$ & 40 & 9.5 & $9.2(3.7-14.7)$ \\
\hline
\end{tabular}

${ }^{a}$ Denominator reflects the number of participants who consented to testing for each biomarker 
Table 3 Predictors of HIV/HBV co-infection among PWID study participants, 2013-2014 ( $N=442)$

\begin{tabular}{|c|c|c|c|c|c|c|c|c|}
\hline Characteristics & $n / N$ & Prevalence of HBV/HIV & Crude OR & $95 \% \mathrm{Cl}$ & $\boldsymbol{p}$-value & $\mathrm{aOR}$ & $95 \% \mathrm{Cl}$ & p-value \\
\hline \multicolumn{9}{|l|}{ City } \\
\hline Maputo & $49 / 318$ & 15.1 & 2.1 & $0.9-3.9$ & 0.01 & 1.5 & $0.7-3.4$ & 0.27 \\
\hline Nampula/Nacala & $10 / 126$ & 7.9 & 1 & & & & & \\
\hline \multicolumn{9}{|l|}{ Age group (years) } \\
\hline $18-24$ & $1 / 83$ & 1.2 & 1 & & & & & \\
\hline$\geq 25$ & $58 / 361$ & 16.1 & 15.7 & $3.4-279.5$ & $<0.01$ & 12.9 & $2.6-233.5$ & $<0.01$ \\
\hline \multicolumn{9}{|l|}{ Gender } \\
\hline Male & $56 / 424$ & 13.2 & 0.9 & $0.3-3.8$ & 0.17 & - & - & - \\
\hline Female & $3 / 20$ & 15.0 & 1 & & & & & \\
\hline \multicolumn{9}{|l|}{ Marital status } \\
\hline Single/never married & $33 / 260$ & 12.7 & 0.8 & $0.4-1.6$ & 0.52 & - & - & - \\
\hline Cohabitating/married & $12 / 93$ & 12.9 & 0.8 & $0.3-1.8$ & 0.63 & - & - & - \\
\hline Widowed/divorced/separated & $14 / 91$ & 15.4 & 1 & & & & & \\
\hline \multicolumn{9}{|l|}{ Education level } \\
\hline No formal education/Primary school & $22 / 189$ & 11.6 & 0.7 & $0.4-1.3$ & 0.37 & - & - & - \\
\hline Secondary/Higher & $37 / 254$ & 14.6 & 1 & & & & & \\
\hline \multicolumn{9}{|l|}{ Age at first drug use (years) } \\
\hline$<18$ & $6 / 50$ & 12.0 & 1 & & & & & \\
\hline $18-24$ & $29 / 213$ & 13.6 & 1.2 & $0.4-3.2$ & 0.76 & - & - & - \\
\hline$\geq 25$ & $22 / 169$ & 13.0 & 1.1 & $0.4-3.1$ & 0.85 & & & \\
\hline \multicolumn{9}{|l|}{ No of sexual partners, last 12 months } \\
\hline 0 & $10 / 89$ & 11.2 & 1 & & & & & \\
\hline 1 & $11 / 85$ & 12.9 & 1.7 & $0.4-2.9$ & 0.73 & - & - & - \\
\hline$\geq 2$ & $35 / 239$ & 14.6 & 1.3 & $0.6-3.0$ & 0.43 & - & - & - \\
\hline \multicolumn{9}{|c|}{ Gave money, good goods or services in exchange for sex in the, past 12 months $^{a}$} \\
\hline Yes & $19 / 182$ & 10.4 & 0.6 & $0.3-1.1$ & 0.10 & - & - & - \\
\hline No & $37 / 231$ & 16.0 & 1 & & & & & \\
\hline
\end{tabular}

Received money, goods or services in exchange for sex, past 12 months

$\begin{array}{llllll}\text { Yes } & 7 / 73 & 9.6 & 0.6 & 0.3-1.3 & 0.27 \\ \text { No } & 49 / 340 & 14.4 & 1 & & \end{array}$

Ever received drugs in exchange for sex, lifetime

$\begin{array}{llllll}\text { Yes } & 10 / 59 & 16.9 & 1.3 & 0.6-2.8 & 0.38 \\ \text { No } & 49 / 384 & 12.8 & 1 & & \end{array}$

Had unprotected sexual intercourse at last sex

$\begin{array}{llllll}\text { Yes } & 22 / 196 & 11.2 & 1.0 & 0.47-2.2 & 0.18 \\ \text { No, used a condom } & 26 / 149 & 15.0 & 1.7 & 0.08-3.7 & 1.01 \\ \text { Not sexually active } & 11 / 98 & & 1 & & \end{array}$

Frequency of drug use, last 12 months

$\begin{array}{llllll}\text { Did not use } & 1 / 22 & 4.3 & 1 & & \\ \text { Daily } & 38 / 249 & 15.3 & 3.9 & 0.7-71.9 & 0.18 \\ \text { Few times per year/month week } & 20 / 172 & 11.6 & 2.8 & 0.6-53.2 & 0.31\end{array}$

Ever shared needles/syringes

\begin{tabular}{|c|c|c|c|c|c|c|c|}
\hline Yes & $42 / 244$ & 17.2 & 2.2 & $1.3-4.2$ & $<0.01$ & 1.8 & $1.2-3.4$ \\
\hline No & $17 / 200$ & 8.5 & 1 & & & & \\
\hline
\end{tabular}


Table 3 Predictors of HIV/HBV co-infection among PWID study participants, 2013-2014 ( $N=442$ ) (Continued)

\begin{tabular}{|c|c|c|c|c|c|c|c|c|}
\hline Characteristics & $n / N$ & Prevalence of HBV/HIV & Crude OR & $95 \% \mathrm{Cl}$ & $\boldsymbol{p}$-value & $\mathrm{aOR}$ & $95 \% \mathrm{Cl}$ & p-value \\
\hline \multicolumn{9}{|c|}{ Shared needles/syringes in the last month } \\
\hline Yes & $22 / 138$ & 15.9 & 1.3 & $0.7-2.4$ & 0.27 & - & - & - \\
\hline No & $37 / 306$ & 12.1 & 1 & & & & & \\
\hline \multicolumn{9}{|c|}{ Ever injected with a previous used needle/syringe } \\
\hline Yes & $56 / 358$ & 15.6 & 5.0 & $1.8-21.1$ & $<0.01$ & 5.3 & $1.9-22.4$ & 0.01 \\
\hline No & 3/85 & 3.5 & 1 & & & & & \\
\hline \multicolumn{9}{|c|}{ Ever shared any other injection equipment ${ }^{b}$} \\
\hline Yes & $18 / 146$ & 12.3 & 0.8 & $0.4-1.5$ & 0.64 & - & - & - \\
\hline No & $35 / 250$ & 14.0 & 1 & & & & & \\
\hline \multicolumn{9}{|c|}{ Had access to new syringes in the past 12 months } \\
\hline Yes & $51 / 382$ & 13.4 & 1 & & & & & \\
\hline No & $7 / 61$ & 11.5 & 0.8 & $0.3-1.8$ & 0.68 & - & - & - \\
\hline \multicolumn{9}{|c|}{ Received condoms in the past 12 months } \\
\hline Yes & $27 / 172$ & 15.7 & 1 & & & & & \\
\hline No & $32 / 269$ & 11.9 & 0.7 & $0.4-1.2$ & 0.25 & - & - & - \\
\hline \multicolumn{9}{|c|}{ Ever incarcerated } \\
\hline Yes & $45 / 296$ & 15.2 & 1.7 & $0.9-3.3$ & 0.09 & 1.2 & $0.6-2.4$ & 0.63 \\
\hline No & $14 / 148$ & 9.5 & 1 & & & & & \\
\hline
\end{tabular}

axcluded female participants

b Other includes spoon, cotton or cleaning agent

In this study, we found that the prevalence of HIV/ HBV and HIV/HCV co-infection among PWID increased with age. Several studies demonstrated that co-infection with $\mathrm{HBV}$ or $\mathrm{HCV}$ increase with age among HIV-infected individuals [31, 32]. Because HIV and viral hepatitis are chronic and sometimes asymptomatic infections, it is likely that individuals are at an even higher risk of progression to chronicity given the combined effects of age and related immune system dysfunction [33].

Our study also showed that PWID who re-used needle/syringe after someone had injected were almost five and 12 times as likely to be co-infected with HIV/HBV and $\mathrm{HIV} / \mathrm{HCV}$, respectively. Other studies have found that HIV and hepatitis transmission are associated with high-risk injection practices such as injection with a syringe previously used by another PWID [2, 9, 10, 30, 34]. Individuals living with $\mathrm{HIV} / \mathrm{HCV}$ co-infection are less likely to clear acute $\mathrm{HCV}$ infection and more likely to transmit the virus which is particularly of concern for PWID who may be sharing used needles [35].

Despite overwhelming evidence of the effectiveness of harm reduction for preventing the spread of HIV and reducing other health issues associated with drug use, global harm reduction service coverage remains insufficient [36]. Mozambique does not have integrated harm reduction programs and policies to reduce the high-risk sexual and drug use behaviors that contribute to the growing
HIV epidemic in the country [18]. In 2018, the first drop-in center for people who use drugs was opened as a demonstration site in Maputo to provide comprehensive medical care for people who use drugs before linkage to more comprehensive healthcare services. Clients receive point-of-care screening for HIV, hepatitis, syphilis, tuberculosis and referrals for clinical care as needed [37]. However, so far, the services are restricted to one urban location in the country.

A comprehensive harm reduction package needs to be adopted and should include access to new needle and syringe; opioid substitution therapy (OST); HIV services (including HIV prevention counseling, testing an ART); prevention and treatment of STIs; prevention, diagnosis and treatment of $\mathrm{TB}$ and viral hepatitis (B and $\mathrm{C}$ ), risk reduction information and education for PWID and their sex partners, and condom distribution programmes for PWID and their sex partners [38-40]. Some countries have adopted an integrated harm reduction package to prevent both HIV and hepatitis infection among PWID, given their similar mode of transmission via sexual exposure and high-burden of infection in specific populations [9, 36, 41]. Efforts to promote condom use must specifically address PWID in an environment free to stigma and discrimination [42].

Although this represents the first analysis of HIV a viral hepatitis among PWID in Mozambique, some limitations should be considered. Given the low sample size, 
Table 4 Correlates of HIV/HCV co-infections among PWID study participants, 2013-2014 (N=422)

\begin{tabular}{|c|c|c|c|c|c|c|c|c|}
\hline Characteristics & $\mathrm{n} / \mathrm{N}$ & Prevalence of HCV/HIV & OR & $95 \% \mathrm{Cl}$ & $\boldsymbol{p}$-value & $\mathrm{aOR}$ & $95 \% \mathrm{Cl}$ & $\boldsymbol{p}$-value \\
\hline \multicolumn{9}{|l|}{ City } \\
\hline Maputo & $8 / 124$ & 38.7 & 9.1 & $4.6-20.9$ & $<0.01$ & 4.4 & $2.0-11.1$ & $<0.01$ \\
\hline Nampula/Nacala & $116 / 300$ & 6.5 & REF & & & & & \\
\hline \multicolumn{9}{|l|}{ Age group (years) } \\
\hline $18-24$ & $2 / 80$ & 2.5 & 1 & & & & & \\
\hline$\geq 25$ & $122 / 344$ & 35.5 & 21.4 & $6.5-131.6$ & $<0.01$ & 22.8 & $4.6-414.6$ & $<0.01$ \\
\hline \multicolumn{9}{|l|}{ Gender } \\
\hline Male & $119 / 408$ & 29.2 & 0.9 & $0.3-2.9$ & 0.86 & - & - & - \\
\hline Female & $5 / 16$ & 31.2 & 1 & & & & & \\
\hline \multicolumn{9}{|l|}{ Marital status } \\
\hline Single/never married & $73 / 249$ & 29.3 & 0.6 & $0.3-1.1$ & 0.12 & 0.72 & $0.4-1.4$ & 0.38 \\
\hline Cohabitating/married & 18/89 & 20.2 & 0.4 & $0.2-0.8$ & $<0.01$ & 1.3 & $0.7-2.6$ & 0.32 \\
\hline Widowed/divorced/separated & $33 / 86$ & 38.4 & 1 & & & & & \\
\hline \multicolumn{9}{|l|}{ Education level } \\
\hline No formal education/Primary school & $57 / 177$ & 32.2 & 1.2 & $0.8-1.9$ & 0.27 & - & - & - \\
\hline Secondary/Higher & $67 / 246$ & 27.2 & 1 & & & & & \\
\hline \multicolumn{9}{|l|}{ Age of first drug use } \\
\hline$<18$ & $12 / 49$ & 24.5 & 1 & & & & & \\
\hline $18-24$ & $57 / 202$ & 28.2 & 1.2 & $0.6-2.5$ & 0.60 & - & - & - \\
\hline$\geq 25$ & $51 / 161$ & 31.7 & 1.4 & $0.7-3.0$ & 0.34 & - & - & - \\
\hline \multicolumn{9}{|l|}{ No of sexual partners, last 12 months } \\
\hline 0 & $27 / 85$ & 31.8 & 1 & & & & & \\
\hline 1 & $23 / 83$ & 27.7 & 0.8 & $0.4-1.5$ & 0.56 & - & - & - \\
\hline$\geq 2$ & $68 / 231$ & 29.4 & 0.9 & $0.5-1.5$ & 0.68 & - & - & - \\
\hline \multicolumn{9}{|c|}{ Gave money, good or services in exchange for sex in the, last 12 months $^{a}$} \\
\hline Yes & $44 / 176$ & 25.0 & 0.6 & $0.4-1.0$ & 0.07 & - & - & - \\
\hline No & $74 / 223$ & 33.2 & 1 & & & & & \\
\hline
\end{tabular}

Received money, goods or services in exchange for sex, last 12 months

$\begin{array}{llllll}\text { Yes } & 15 / 70 & 21.4 & 0.6 & 0.3-1.1 & 0.10 \\ \text { No } & 103 / 329 & 31.3 & \text { REF } & & \end{array}$

Ever received drugs in exchange for sex, lifetime

$\begin{array}{llllll}\text { Yes } & 16 / 57 & 28.1 & 0.9 & 0.4-1.7 & 0.82 \\ \text { No } & 108 / 366 & 29.5 & 1 & & \end{array}$

Had unprotected sexual intercourse at last sex

$\begin{array}{llllll}\text { Yes } & 38 / 191 & 19.9 & 0.55 & 0.3-1.0 & <0.05 \\ \text { No, used a condom } & 86 / 233 & 36.9 & 1.6 & 0.9-2.7 & 1.12 \\ \text { Not sexually active } & & & \text { REF } & & \end{array}$

Frequency of drug use, last 12 months

$\begin{array}{llllllll}\text { Did not use } & 1 / 22 & 43.2 & 1 & & & \\ \text { Daily } & 102 / 236 & 12.7 & 15.9 & 3.3-288.9 & <0.01 & - & - \\ \text { Few times per year/month week } & 21 / 145 & 14.5 & 3.0 & 0.5-55.9 & 0.29 & - & - \\ \text { Ever shared needles or syringes } & & & & & & \\ \text { Yes } & 96 / 236 & 40.7 & 3.9 & 2.5-6.4 & <0.01 & 4.0 & 2.1-7.7 \\ \text { No } & 28 / 188 & 14.9 & 1 & & & <0.01\end{array}$


Table 4 Correlates of HIV/HCV co-infections among PWID study participants, 2013-2014 (N=422) (Continued)

\begin{tabular}{|c|c|c|c|c|c|c|c|c|}
\hline Characteristics & $n / N$ & Prevalence of HCV/HIV & OR & $95 \% \mathrm{Cl}$ & $\boldsymbol{p}$-value & $\mathrm{aOR}$ & $95 \% \mathrm{Cl}$ & $\boldsymbol{p}$-value \\
\hline \multicolumn{9}{|c|}{ Shared syringes in the past month } \\
\hline Yes & $55 / 133$ & 41.4 & 2.2 & $1.4-3.5$ & $<0.01$ & 0.53 & $0.4-1.1$ & 0.08 \\
\hline No & $69 / 291$ & 23.7 & 1 & & & & & \\
\hline \multicolumn{9}{|c|}{ Ever injected with a previous used needle/syringe } \\
\hline Yes & $119 / 342$ & 34.7 & 7.9 & $3.4-23.1$ & $<0.01$ & 12.1 & $4.1-46.3$ & $<0.01$ \\
\hline No & $5 / 80$ & 6.2 & 1 & & & & & \\
\hline \multicolumn{9}{|c|}{ Ever shared any other injection equipment ${ }^{b}$} \\
\hline Yes & $45 / 141$ & 3.19 & 1.3 & $0.8-2.1$ & 0.26 & - & - & - \\
\hline No & $63 / 238$ & 26.5 & 1 & & & & & \\
\hline \multicolumn{9}{|c|}{ Had access to brand new syringes in the past 12 months } \\
\hline Yes & $106 / 365$ & 29.0 & 1.1 & $0.5-1.9$ & 0.75 & - & - & - \\
\hline No & $18 / 58$ & 31.0 & 1 & & & & & \\
\hline \multicolumn{9}{|c|}{ Received condom in the past 12 months } \\
\hline Yes & $51 / 165$ & 30.9 & 1 & & & & & \\
\hline No & $73 / 257$ & 28.4 & 0.8 & $0.5-1.3$ & 0.58 & - & - & - \\
\hline \multicolumn{9}{|c|}{ Ever incarcerated } \\
\hline Yes & $98 / 282$ & 34.8 & 2.3 & $1.4-3.9$ & $<0.01$ & 1.3 & $0.7-2.4$ & 0.40 \\
\hline No & $26 / 142$ & 18.3 & 1 & & & & & \\
\hline
\end{tabular}

axcluded female participants

b Other includes spoon, cotton or cleaning agent

this secondary analysis pooled results from the two survey cities resulting in the loss of social networks and chains. As such, these results should be interpreted with caution when generalizing to the full PWID population in these cities. Also, there was a change in recruitment criteria during the survey, to include individuals who ever injected drugs without a prescription, which may have resulted in including participants with lower recent risk of HIV and hepatitis infection. However, since most participants reported having injected during the last month prior to the survey, the change in inclusion criteria may not have had a significant influence. As is the case with all cross-sectional surveys, self-reported data could be subject to recall bias and/or social desirability bias and it is also difficult to assess causality. Finally, many participants refused to have the HCV test $(9.4 \%$ of the sample), perhaps due an absence of point-of-care testing or treatment options within the national health care system at the time of survey implementation, which may underestimate the true prevalence of $\mathrm{HCV}$ in the population.

\section{Conclusions}

This was the first analysis to evaluate the epidemiological profile and risk factors for HIV/HBV and HIV/ HBC co-infections among participants in the PWID BBS survey in Mozambique. The high burden of disease among this population requires a enhance public health interventions since HIV and viral hepatitis co-infection increases morbidity and mortality, as well changes the natural history of all infections. An integrated harm reduction strategy is necessary to address all infections simultaneously. These services must be enhanced at health facilities but implementation must also be decentralized through community-based outreach, drop-in centres and special environments, such as prison settings. Further investigation should assess the feasibility of introducing HBV vaccination in this high-risk population within the Mozambican context, as an important strategy prevent associated co-morbidities and improve their overall health status.

\section{Abbreviations}

ART: Antiretroviral therapy; Anti-HCV: Hepatitis C virus antibody; BBS: Biological and behavioral survey; HBsAg: Hepatitis B surface antigen; HBV: Hepatitis B virus; HCV: Hepatitis C virus; HIV: Human immunodeficiency virus; PWID: People who inject drugs; RDS: Respondent-driven sampling; STI: Sexual Transmitted Infections

\section{Acknowledgments}

The study team acknowledges the immense contributions of all Mozambique BBS Technical Working Group, and all others that have contributed to the successful implementation BBS among PWID in Mozambique.

Authors' contributions

CSB: study design and manuscript drafting. CSB, MK, TK, PR and IS: data analysis and interpretation. MB, EF, HFR, MT, and SL: critical revision. All authors read and approved the manuscript. 


\section{Funding}

This paper used data from research supported by the President's Emergency Plan for AIDS Relief (PEPFAR) through the U.S. Centers for Disease Control and Prevention (CDC) Mozambique Country Office under the terms of Cooperative Agreement Number \#5U2GPS002829. The findings and conclusions in this article are those of the authors and do not represent the official position of the funding agencies.

\section{Availability of data and materials}

The dataset analyzed for the current study are fully available at the Data Management Unit of the Mozambique National Institute of Health (INS) data repository for researchers who meet the criteria for access to confidential data following concept note submission. For more information can be found in: www.ins.gov.mz or through: secretaria@ins.gov.mz.

\section{Ethics approval and consent to participate}

The main study protocol was approved by the Mozambican National Bioethics Committee for Health and by the Institutional Review Board of the University of California, San Francisco. For all participants written informed consent was obtained.

\section{Consent for publication}

Not applicable.

\section{Competing interests}

The authors declare that they have no competing interests.

\section{Author details}

${ }^{1}$ Instituto Nacional de Saúde (INS), Maputo, Mozambique. ${ }^{2}$ Department of Public Health and Primary Care, Faculty of Medicine and Health Sciences, Ghent University, Ghent, Belgium. ' University of California, San Francisco, USA. ${ }^{4}$ National Program to Control STIs and HIV/AIDS, Ministry of Health, Maputo, Mozambique. ${ }^{5}$ International Center Aids Program (ICAP), Maputo, Mozambique. ${ }^{6}$ School of Public Health, Rutgers University, Piscataway, NJ, USA. ${ }^{7}$ Department of OBGYN, Aga Khan University, Nairobi, Kenya. ${ }^{8}$ Department of Population Health, Aga Khan University, Nairobi, Kenya. ${ }^{9}$ Department of Epidemiology and Preventive Medicine, Monash University, Melbourne, Australia. ${ }^{10}$ Burnet Institute, Melbourne, Australia.

Received: 24 January 2020 Accepted: 29 May 2020

Published online: 03 June 2020

\section{References}

1. Degenhardt L, Peacock A, Colledge S, Leung J, Grebely J, Vickerman P, et al. Global prevalence of injecting drug use and sociodemographic characteristics and prevalence of HIV, HBV, and HCV in people who inject drugs: a multistage systematic review. Lancet Glob Health. 2017;5(12): e1192-207.

2. Buchanan R, Khakoo SI, Coad J, Grellier L, Parkes J. Hepatitis C biobehavioural surveys in people who inject drugs-a systematic review of sensitivity to the theoretical assumptions of respondent driven sampling. Harm Reduct J. 2017;14(1):44

3. Heckathorn DD. Respondent-driven sampling II: deriving valid population estimates from chain-referral samples of hidden populations. Soc Probl. 2002;49(1):11-34.

4. Instituto Nacional de Saúde (INS), Instítuto Nacional de Estatística (INE), ICF Macro. Inquérito nacional de prevalência, riscos comportamentais e informação sobre o HIV e SIDA em Moçambique 2009. 2010.

5. Conselho de Ministros. Plano Estratégico Nacional de Resposta ao HIV e SIDA 2010-2014. Available from: https://www.lo.org/wcmsp5/groups/ public/---ed_protect/---protrav/---ilo_aids/documents/legaldocument/ wcms_172584.pdf. Accessed 28 Feb 2020.

6. MISAU, INS. Final report: the Mozambique integrated biological and behavioral survey among people who inject Drugs, 2014. Mozambique. 2017. Available from: https://globalhealthsciences.ucsf.edu/sites/ globalhealthsciences.ucsf.edu/files/pub/pwid-final-report-20180329.pdf.. Accessed 28 Feb 2020

7. Semá Baltazar C, Horth R, Boothe M, Sathane I, Young P, Chitsondzo Langa D, et al. High prevalence of HIV, HBsAg and anti-HCV positivity among people who injected drugs: results of the first bio-behavioral survey using respondent-driven sampling in two urban areas in Mozambique. BMC Infect Dis. 2019;19(1):1022

8. Umutesi J, Simmons B, Makuza JD, Dushimiyimana D, Mbituyumuremyi A, Uwimana JM, et al. Prevalence of hepatitis B and $C$ infection in persons living with HIV enrolled in care in Rwanda. BMC Infect Dis. 2017;2:17.

9. Bagheri Amiri F, Mostafavi E, Mirzazadeh A. HIV, HBV and HCV Coinfection prevalence in Iran - a systematic review and meta-analysis. PLoS One. 2016; 31:11(3).

10. Ray Saraswati L, Sarna A, Sebastian MP, Sharma V, Madan I, Thior I, et al. HIV, hepatitis B and C among people who inject drugs: high prevalence of HIV and hepatitis C RNA positive infections observed in Delhi, India. BMC Public Health. 2015;30:15.

11. Mansha S, Imran M, Shah AMUH, Jamal M, Ahmed F, Atif M, et al. Hepatitis B and C virus infections among human immunodeficiency virus-infected people who inject Drugs in Lahore, Pakistan. Viral Immunol. 2017;30(5):366-70

12. Thornton AC, Jose $S$, Bhagani $S$, Chadwick D, Dunn D, Gilson R, et al. Hepatitis B, hepatitis C, and mortality among HIV-positive individuals. AIDS. 2017:31(18):2525-32

13. Viegas EO, Tembe N, Macovela E, Gonçalves E, Augusto O, Ismael N, et al. Incidence of HIV and the prevalence of HIV, hepatitis B and syphilis among youths in Maputo, Mozambique: a cohort study. PLoS One. 2015;10(3): e0121452.

14. Chambal LM, Samo Gudo E, Carimo A, Corte Real R, Mabunda N, Maueia C, et al. HBV infection in untreated HIV-infected adults in Maputo, Mozambique. PLoS One. 2017;31, 12(7)

15. WHO. Global health sector strategy on viral sector strategy on viral hepatites 2016-2021. Towards ending viral hepatites 2016. Available from: https://www.who.int/hepatitis/strategy2016-2021/ghss-hep/en/. Accessed 28 Feb 2020.

16. UNAIDS. 90-90-90 an ambitious treatment target to help end the AIDS epidemic. Geneva: 2014. Available from: https://www.unaids.org/sites/ default/files/media_asset/90-90-90_en_0.pdf. Accessed 28 Feb 2020.

17. United Nations. A/RES/70/1. Transforming our world: the 2030 agenda for sustainable development: - Resolution adopted by the General Assembly on 25 September 2015. Available from: https://sustainabledevelopment.un.org/ post2015/transformingourworld. Accessed 5 Feb 2020.

18. Semá Baltazar C, Boothe M, Kellogg T. Young people who inject drugs in Mozambique: should we emphasize them in the National Harm Reduction Plan? Harm Reduct J. 2020;26:17.

19. Dengo-Baloi LC, Boothe MA, Semá-Baltazar CA, Sathane I, Langa DC, Condula $\mathrm{M}$, et al. Access to and Use of Health and Social Services among People who Inject Drugs in two urban areas of Mozambique, 2014: Qualitative results from a formative assessment. BMC Public Health. 2020. https://doi.org/10.21203/rs.2.18608/v2.

20. Malekinejad M, Johnston LG, Kendall C, Kerr LRFS, Rifkin MR, Rutherford GW Using respondent-driven sampling methodology for HIV biological and behavioral surveillance in international settings: a systematic review. AIDS Behav. 2008;12(1):105-30.

21. Heckathorn DD. Respondent-driven sampling: a new approach to the study of hidden populations. Soc Probl. 1997:44(2):174-99.

22. INS, CDC, UCSF Global Health Science, MITRAB, I-TECH. Final Report. Maputo: The Integrated Biological and Behavioral Survey among Mozambican Workers in South African Mines, 2012; 2013. Available from: https://globalhealthsciences.ucsf.edu/sites/globalhealthsciences.ucsf.edu/ files/pub/ibbs-mine-workers-final-report.pdf. Accessed 28 Feb 2020.

23. INS, CDC, UCSF, PSI, Pathfinder International, I-TECH, et al. Final report: the integrated biological and behavioral survey among men who have sex with men, 2011. Maputo: 2013. Available from: https://globalhealthsciences.ucsf. edu/sites/globalhealthsciences.ucsf.edu/files/pub/ibbs-msm-final-report.pdf. Accessed 28 Feb 2020

24. INS, CDC, UCSF Global Health Science, DPS Manica, CIDI, Pathfinder International, et al. Final Report. Maputo: The Integrated Biological and Behavioral Survey among Long Distance Truck Drivers, 2012. 2012. Available from: https://globalhealthsciences.ucsf.edu/sites/globalhealthsciences.ucsf. edu/files/pub/ibbs-long-distance-truck-drivers-final-report.pdf. Accessed 28 Feb 2020.

25. INS, CDC, Pathfinder International, I-TECH. Final report: the integrated biological and behavioral survey among female sex workers, Mozambique 2011-2012. Maputo: 2013. Available from: https://ins.gov.mz/sites/default/ files/2019-11//BBS-FSW-Final-Report.pdf. Accessed 28 Feb 2020 
26. Gile KJ, Johnston LG, Salganik MJ. Diagnostics for Respondent-driven Sampling. J R Stat Soc Ser A Stat Soc. 2015;178(1):241-69. https://doi.org/10 1111/rssa.12059

27. Stabinski L, O'Connor S, Barnhart M, Kahn RJ, Hamm TE. Prevalence of HIV and Hepatitis B Virus Co-Infection in Sub-Saharan Africa and the Potential Impact and Program Feasibility of Hepatitis B Surface Antigen Screening in Resource-Limited Settings. J Acquir Immune Defic Syndr. 2015;68:S274-85.

28. Klingler C, Thoumi Al, Mrithinjayam VS. Cost-effectiveness analysis of an additional birth dose of hepatitis $B$ vaccine to prevent perinatal transmission in a medical setting in Mozambique. Vaccine. 2012;31(1):252-9.

29. Rao VB, Johari N, du Cros P, Messina J, Ford N, Cooke GS. Hepatitis C seroprevalence and HIV co-infection in sub-Saharan Africa: a systematic review and meta-analysis. Lancet Infect Dis. 2015;15(7):819-24.

30. Azevedo TCL, Zwahlen M, Rauch A, Egger M, Wandeler G. Hepatitis C in HIV-infected individuals: a systematic review and meta-analysis of estimated prevalence in Africa. J Int AIDS Soc. 2016;9(1):19.

31. Edward J. Wing. The aging population with HIV infection. Trans Am Clin Climatol Assoc. 2017;128:131-44.

32. Rodriguez-Penney AT, ludicello JE, Riggs PK, Doyle K, Ellis RJ, Letendre SL, et al. Co-morbidities in persons infected with HIV: increased burden with older age and negative effects on health-related quality of life. AIDS Patient Care STDs. 2013;27(1):5-16.

33. Falade-Nwulia O, Thio CL. Liver disease, HIV and aging. Sex Health. 2011;8(4): 512-20. .

34. Kilonzo SB, Gunda DW, Mpondo BCT, Bakshi FA, Jaka H. Hepatitis B virus infection in Tanzania: current status and challenges. J Trop Med. 2018. https://doi.org/10.1155/2018/4239646.

35. Shapatava E, Nelson KE, Tsertsvadze T, del Rio C. Risk behaviors and HIV, hepatitis $B$, and hepatitis $C$ seroprevalence among injection drug users in Georgia. Drug Alcohol Depend. 2006;82(Suppl 1):S35-8.

36. Cook C, Phelan M, Sander G, Stone K, Murphy F. The case for a harm reduction decade: progress, potential and paradigm shifts. Harm Reduction International; 2016. Available from: https://www.hri.global/files/2016/03/10/ Report_The_Case_for_a_Harm_Reduction_Decade.pdf. Accessed 28 Feb 2020.

37. González A, Malm A, Morfino L, Silva C. Overcoming barriers for treating people who use drugs in an urban setting. Alternatives Humanitaires. 10th ed. 2019;79-88. Available from: http://alternatives-humanitaires.org/wpcontent/uploads/2019/03/AH_N10_3_Focus_5_MSF_VEN.pdf. Accessed 5 Feb 2020

38. Tun W, Sheehy M, Broz D, Okal J, Muraguri N, Raymond HF, et al. HIV and STI prevalence and injection behaviors among people who inject Drugs in Nairobi: results from a 2011 bio-behavioral study using respondent-driven sampling. AIDS Behav. 2015;19(Suppl 1):24-35.

39. Scheibe A, Young K, Moses L, Basson RL, Versfeld A, Spearman CW, et al. Understanding hepatitis $B$, hepatitis $C$ and HIV among people who inject drugs in South Africa: findings from a three-city cross-sectional survey. Harm Reduction J. 2019;16(1):28.

40. Drugs UNO on, Crime JUNP on H. Implementing comprehensive HIV and HCV programmes with people who inject drugs: practical guidance for collaborative interventions. United Nations Office on Drugs and Crime Vienna; 2017.

41. Larney S, Peacock A, Leung J, Colledge S, Hickman M, Vickerman P, et al. Global, regional, and country-level coverage of interventions to prevent and manage HIV and hepatitis C among people who inject drugs: a systematic review. Lancet Glob Health. 2017;5(12):e1208-20.

42. Sharma V, Tun W, Sarna A, Saraswati LR, Pham MD, Thior I, et al. Prevalence and determinants of unprotected sex in intimate partnerships of men who inject drugs: findings from a prospective intervention study. Int J STD AIDS. 2019;30(4):386-95.

\section{Publisher's Note}

Springer Nature remains neutral with regard to jurisdictional claims in published maps and institutional affiliations.

Ready to submit your research? Choose BMC and benefit from:

- fast, convenient online submission

- thorough peer review by experienced researchers in your field

- rapid publication on acceptance

- support for research data, including large and complex data types

- gold Open Access which fosters wider collaboration and increased citations

- maximum visibility for your research: over $100 \mathrm{M}$ website views per year

At BMC, research is always in progress.

Learn more biomedcentral.com/submissions 